\title{
Fluoxetine Affects Glycolytic Pathway of C6 Rat Glioma Cells
}

\author{
Ahmed S. Hisab, M.phil. \\ Medical School, University of Nottingham, Nottingham, UK
}

Doi: 10.19044/esj.2018.v14n9p12 URL:http://dx.doi.org/10.19044/esj.2018.v14n9p12

\begin{abstract}
Antidepressants (ADs) such as fluoxetine is known to target and inhibit the electron transport chain of mitochondrial, effects on rat C6 glioma cell function are expected. Also, it has been shown that fluoxetine can inhibit mitochondrial respiration in pancreatic beta cells; however whether this drug can also directly affect glycolytic metabolism is unknown. To address this idea, I have investigated effect of fluoxetine on the bioenergetics of C6 glioma. MTS assay was conducted as an indicator of the metabolic activity of C6 cell lines. Oxidative respiration was measured via oxygen consumption rate (OCR), anaerobic glycolysis was determined with lactate electrodes, where mitochondrial redox state was monitored via NAD (P) H autofluorescence. The metabolic assays showed glucose stimulated MTS reduction cells in a time and concentration dependent manner whereas, the other three mitochondrial fuels did not stimulated it in C6 glioma cells. Methylpyruvate substrate stimulated OCR, neither both glucose and $\alpha$-ketoisocaproate. Glucose inhibited OCR and increased lactate production compared to the control. Glucose failed to affect NADPH levels. Fluoxetine inhibited OCR at $10 \mathrm{mM}$ glucose. However, it did not affect OCR at $10 \mathrm{mM} \alpha$-ketoisocaproate. The above results showed that C6 glioma cells are mainly depending on the glycolytic pathway and that was inhibited by Fluoxetine. In conclusion, since fluoxetine was inactive in the presence of $\alpha$-ketoisocaproate our data suggest that the point of major action for these ADs in C6 glioma cells is glycolysis.
\end{abstract}

Keywords: Fluoxetine, OCR, Lactate production, NAD(P)H, MTS , C6 glioma rat cells

\section{Introduction}

Glia cells compromise over half of the brain volume. They are located in the central and peripheral nervous system where they form Schwann cells in the periphery and neuralgia cells in the central nervous system. Neuroglia 
cells are considered as essential cells in the brain for its survival, their number is much more than for neurons.

Gliocytes have a major role in the energy supply, homeostasis, neurogenesis and synaptogenesis in the brain (Alvarez-Maubecin et al., 2000); (Srebro and Dziobek, 2001);(Kreutzberg, 1996); (Tardy et al., 1991). Early studies by Gee and colleagues pointed out that astrocytes are one of the most important type of glial cells that comprises $90 \%$ of brain and several studies have shown their benefits in the modulation of brain function (Gee and Keller, 2005).They have the important role to control the extracellular such as, dopamine, glutamate, norepinephrine, serotonin, Acetylcholine and GABA (gamma-amino butyric acid) level of some ions such as $\mathrm{K}^{+}$ions and neurotransmitters in the extracellular space. For instance, astrocytes express receptors for wide range of neurotransmitters and can liberate various kinds of neuroactive substrates and trophic factors. On the basis of th-7896+ese, they probably assist features development and function of synapses.

\section{Astrocytes}

Astrocytes are the most abundant cell component in glial cells and have various supporting functions (Hu et al., 2008). They have very important role in metabolic interaction between astrocytes and neurons (Magistretti, 2008a). In addition, it has been suggested that astrocytes are a valuable store of glycogen, such that as, when hypoglycaemia occurs, this may maintain the energy supply of neurones (Dienel and Cruz, 2006; Brown et al., 2004; Magistretti, 2008b; Vilchez et al., 2007). Glycogen may be quickly transformed into pyruvate or/and lactate and also metabolized via the tricarboxylic acid (TCA) cycle, or it could be used for biosynthesis of glutamate and glucose (Hamprecht et al., 2005; Ghosh et al., 2005). It has been thought that the glucose and lactate produced by glia might be transmitted to neurones for fuel (Brown et al., 2004; Dringen et al., 1993), the so called Astrocytes, Neuron Lactate Shuttle Hypothesis [ANLSH](Magistretti, 2008a).

Proton- linked membrane transporters that carry lactate, pyruvate and ketone bodies through the cell membrane. Such transporters are expressed universally by astrocytes (Pierre and Pellerin, 2005; Rinholm et al., 2011). There is growing evidence confirm that the rate of glycolysis in astrocytes is much higher that neurons which depends on mitochondrial respiration for their energy (Occhipinti et al., 2007). Furthermore, more current studies have addressed the critical question of which biochemical steps confirm whether astrocytes is rather oxidative (oxidizing both glucose and lactate) or exhibit some glycolytic features (by exporting rather than consuming lactate)(Neves et al., 2012). 
The onset of depression is believed to be associated with a lack of monoamine/ catecholamine neurotransmission in the central nervous system, and as a consequence therapeutic regimes mostly focus on the use of drug classes that are able to down-regulate or upregulate central synaptic monoamine/catecholamine neurotransmission. These drugs include tricyclic anti-depressants (TCA), monoamine oxidase inhibitors (MAOI), selective serotonin reuptake inhibitors (SSRI) and non-selective serotonin reuptake inhibitors (NSRI) as well as emerging atypical classes (McIntyre et al., 2006; Kiss, 2008). According to some researchers (Lustman et al., 1992; Derijks et al., 2008; Brown et al., 2008).

Indeed, it is well established that at high doses, members of the typical class of antidepressants, such as fluoxetine can be cytotoxic human carcinoma HT29 cells (Arimochi and Morita, 2006) as well as inhibiting the proliferation in a dose dependent manner breast cancer cells (Abdul et al., 1995). Several studies by (Spanová et al., 1997; Levkovitz et al., 2005) indicated that fluoxetine causes apoptosis in rat glioblastoma cells and human neuroblastoma cells. On the contrary, a study by (Mercier et al., 2004) mainly in vivo, found that antidepressants induce neuroprotection and facilitation of neural cell survival via activation in the brain of neurotrophic factors, such as brain derived neurotrophic factor (BDNF) and nerve growth factor (NGF). Increased BDNF was found in rat hippocampus, following reboxetine and citalopram treatment (Russo-Neustadt et al., 2004). In addition, Several studies have demonstrated that fluoxetine increases the proliferation of B16F10 melanoma cells and C3 fibrosarcoma cells both in vivo and in vitro (Brandes et al., 1992) as well as fluoxetine and desipramine, a tricyclic antidepressant, inhibit metastasis of B16F10 lineage in young mice, but promote it in old mice (Kubera et al., 2009). The mechanisms that underlie Antidepressants neurotoxicity remain unclear. Their neurotoxicity may result from disruptive actions on mitochondria and oxidative respiration. For example, previous investigations showed that antidepressants such as fluoxetine especially at dosages at the higher end of their therapeutic window, affect the function of C6 rat glioma cells of; a phenomena that will have consequences for impairment of mitochondrial function of human glioma cells (Daley et al., 2005). However, whether this drug can also directly affect glycolytic metabolism is unknown. I have sought to answer this question by studying metabolic profile of C6 rat glioma cells. MTS reduction by using MTS assay, oxidative respiration was measured via oxygen consumption rate (OCR), anaerobic glycolysis was determined with lactate electrodes, where mitochondrial redox state was monitored via $\mathrm{NAD}(\mathrm{P}) \mathrm{H}$ autofluorescence. 


\section{Experimental procedure \\ Cell lines used}

C6 rat glioma cell lines (ATCCCRL-2199) is derived from the Nnitrosomethylurea-induced glial rat in 1989. This cell line maintained in G418 media for 14 days, cloned, and evaluated for beta-gal production. LacZ7 is a specific markers express in rat brain can be detected by histochemistry. These cells are adherent and when grown in the T-75 $\mathrm{cm}^{2}$ flasks, they form stable monolayers (Benda et al., 1968). Cell cultured medium was Dulbecco's Modified Eagle's Medium (DMEM) containing 10\% (v/v) fetal calf serum, $1 \%$ (w/v) Penicillin 1000 unit $/ \mathrm{ml}$ - streptomycin $0.1 \mathrm{mg} / \mathrm{ml}$ and $2 \mathrm{mM}$ glutamine. Passage number used 66-100. This cell line is an astrocytic cell culture model, which is less aerobic and more dependent on glycolysis for its bioenergetics.

\section{MTS Assay}

The water-soluble salt MTS (3-[4, 5dimethylthiazol-2-yl] -5-[3carboxymethoxy-phenyl] -2-[4-sulfophenyl] -2H-tetrazolium) assay depends on reduction of the MTS substrate to produce coloured formazan. This assay does not need to solubilize the cells by using acidified isopropanol, which may disrupt the cells integrity. MTS receives electrons via an intermediate electron acceptor Phenazine methosulfate (PMS) which amplifies (fluorescence signal at $490 \mathrm{nM}$ (Cory et al., 1991; Janjic and Wollheim, 1992; Segu et al., 1998). The MTS assay was performed according to the manufacturer's instructions (Celltiter 96 aqueous nonradioactive cell- proliferation assay, Promega, Madison, WI). The absorbance was measured at $490 \mathrm{~nm}$ by plate reader. Readings were corrected for the background by subtracting the blank (MTS/PMS regent in Hanks without the cells) from the readings. Three experiments have been performed with triplicate wells in each experiment.

\section{Oxygen Consumption Rate (OCR)}

Mitochondrial respiratory rate of 1.1B4 and MIN6 cell suspensions were measured polarographically using Clark Oxygen. The partial pressure of $\mathrm{O}_{2}\left(\mathrm{PO}_{2}\right)$ was measured at a polarographic voltage of $0.6 \mathrm{~V}$ with electrodes previously calibrated at $100 \%$ air saturation (vigorous gassing with air, $0.25 \mathrm{mM}$ ) and $0 \%$ (addition of $\mathrm{Na}_{2} \mathrm{~S}_{2} \mathrm{O}_{4}$ ) (Daunt et al., 2006). The background of Oxygen consumption by electrode was determined by the addition of $6 \mathrm{mM}$ sodium azide to block oxidative respiration at cytochrome $\mathrm{C}$.

\section{Lactate production}

The rate of lactate production of both1.1B4 and MIN6 was measured polarographically with sarissa lactate enzyme electrodes (Sarissa Biomedical Ltd Coventry, UK) as previously mentioned by Brown et al., 2012. $4 \mathrm{~mL}$ of 
cell suspension were loaded in to a chamber, where the potential of the lactate electrode was set at $500 \mathrm{mV}$ relative to $\mathrm{Ag} / \mathrm{AgCl}$ reference electrode. Electrical current will be generated due to the oxidation of lactate by the lactate oxidase enzyme on the surface of a carbon fiber electrode. This current is a stoichiometric measure of lactate concentration. The lactate output rate was calculated according to the following equation:

ESubstrate (nmol 107 cell-1 min-1) = (substrate)*60/ (cells count)/calibration value.

\section{NAD (P) H measurements}

$\mathrm{NAD}(\mathrm{P}) \mathrm{H}$ experiments were carried out using epifluorescence microscope as previously described (e.g. Duchen, 1992a,b; Duchen and Biscoe, 1992a,b). NAD(P)H produced from glucose and/or amino acid metabolism in the mitochondria . Cells were excited by light at $350 \mathrm{~nm}$ and measured with a bandpass fliter combination between 400 and $500 \mathrm{~nm}$. To normalize the $\mathrm{NAD}(\mathrm{P}) \mathrm{H}$ response experiments, $10 \mathrm{mM}$ glucose was used to reach a maximal response and this was set as a $100 \%$.

\section{Glucose-response relationships}

The glucose-response relationships were quantified by best fits of the data with the following equation using prism via best fit non-linear regression:

$$
Y=\frac{Y_{\text {MAX }}-Y_{\text {MIN }}}{1+\left(E C_{50} / G\right)^{h}}+Y_{\text {MIN }}
$$

Where $\mathrm{G}$ is the concentration of glucose, $\mathrm{EC}_{50}$ is the concentration that Produces the half-maximal response, $\mathrm{Y}$ is the response magnitude, $\mathrm{Y}_{\text {MAX }}$ is the maximal response, $\mathrm{Y}_{\mathrm{MIN}}$ is the minimal response, and $\mathrm{h}$ is an index of slope. Fits were performed in PRISM 6 (GraphPad Software Inc., San Deigo, CA).

\section{Concentration-response relationships}

Concentration-response relationships were constructed from multiple experiments using solely single concentrations. The Concentration-response relationships were quantified by fitting the data (without weighting) with the following sigmoid equation:

$$
Y=(100-Y \max )+\frac{Y \max }{\left(1+\left([\mathrm{AD}] / \mathrm{EC}_{50}\right)^{n}\right)}
$$


Where $\mathrm{Y}$ is the magnitude of effect as a percentage of Ymax, the maximum effect, $[\mathrm{AD}]$ is the concentration of antidepressant, $\mathrm{EC}_{50}$ is the concentration that produces half-maximal effect (Ymax/2) and $\mathrm{h}$ is an index of slope. Fits were performed in PRISM 6 (GraphPad Software Inc., San Deigo, CA).

\section{Statistical analysis}

Data are expressed as mean \pm S.E.M. Parametric statistical analysis was used if the data was checked to be normally distributed (D' Agostino Pearson ominubus normality test). Statistical analysis was assessed in Prism (6.0, GraphPad software, San Diego California, USA). $\mathrm{EC}_{50}$ and $\mathrm{h}$ values are quoted with 95\% confidence intervals. Statistical significant was accepted at $P<0.05$.

\section{Results}

\section{Responses to Fuels}

There was slight increase in MTS reduction with increasing glucose concentration at $1 \mathrm{mM}$ glucose, which saturated at $10 \mathrm{mM}$ in the presence and absence of azide (Fig 1A). The $\mathrm{EC}_{50}$ of glucose stimulated MTS reduction was $1.13 \mathrm{mM}(0.9$ to $1.495 \% \mathrm{CI})$ and $\mathrm{h}$ of 1 in the absence of azide (Fig. 1A). However, $\mathrm{EC}_{50}$ of glucose stimulated MTS reduction was $1.5 \mathrm{mM}$ (1.4 to 2.6 95\% CI) and $\mathrm{h}$ of 1 in the presence of azide (Fig.1A). On the contrary, 3-MG $(10 \mathrm{mmol} / \mathrm{L})$, a non metabolizable analog of glucose, failed to stimulate MTS reduction in HIT-T15 cells (not shown). However, MP which is preferentially metabolized in the mitochondria of pancreatic beta cells (Segu et al., 1998) failed to stimulate MTS reduction compared to the vehicle control $\left(\mathrm{H}_{2} \mathrm{O}\right)$.(Fig 1B) Both KIC and LEU (pure mitochondrial fuels) (Segu et al., 1998) did not stimulate MTS reduction in the presence and absence of azide (Fig.1C\&D). Although the increments in MTS signal which found in the presence of glucose in contrast to MP, KIC and LEU failed to affect MTS reduction, these studies suggest that the predominate path is glycolytic pathway in C6 glioma cells. 

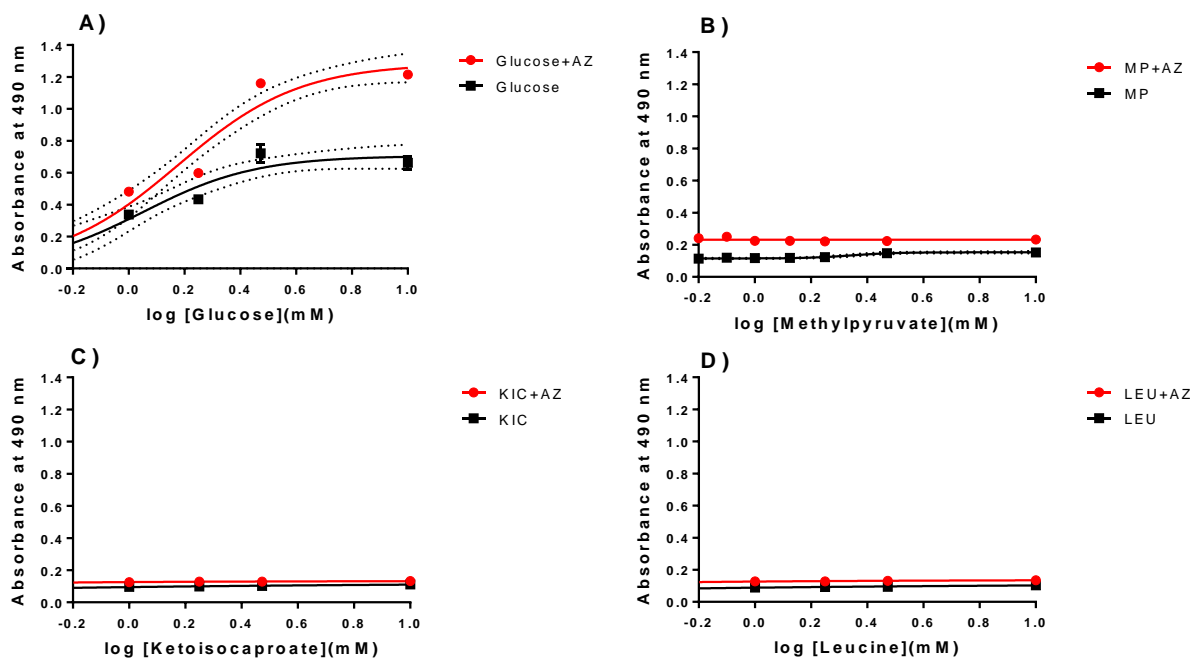

Figure 1: Effects of pure mitochondrial fuels with azide (AZ) and without AZ on MTS reduction in C6 glioma cells: effects of glucose (A), Methylpyruvate (MP) (B),

Ketoisocaproate (KIC) (C) Leucine (LEU) (D). Cells were incubated for 120 minute. Data are means \pm SEM. $\mathrm{N}=9$ experiments.

Since glucose failed to increase oxygen consumption rate (OCR) in C6 glioma cells (as shown in figure 2A), it is difficult to determine if an increased metabolism causes an increase OCR. Thus, we used $\alpha$-ketoisocaproate (KIC) (Duchen et al., 1993; Gao et al., 2003; Daunt et al., 2006) and methylpyruvate (MP)(Jijakli et al., 1996) (Fuels that feed directly into the mitochondrial tricarboxylic acid cycle. MP significantly stimulated $\Delta \mathrm{O}_{2}$ compared to the control $\left(\mathrm{H}_{2} \mathrm{O}\right)(\mathrm{P}<0.01$, Dunnets multicomparison test) in C6 glioma cells (Fig. 2B). However, KIC failed to stimulate OCR compared to the vehicle control $\left(\mathrm{H}_{2} \mathrm{O}\right)$ (Fig. 2C). 

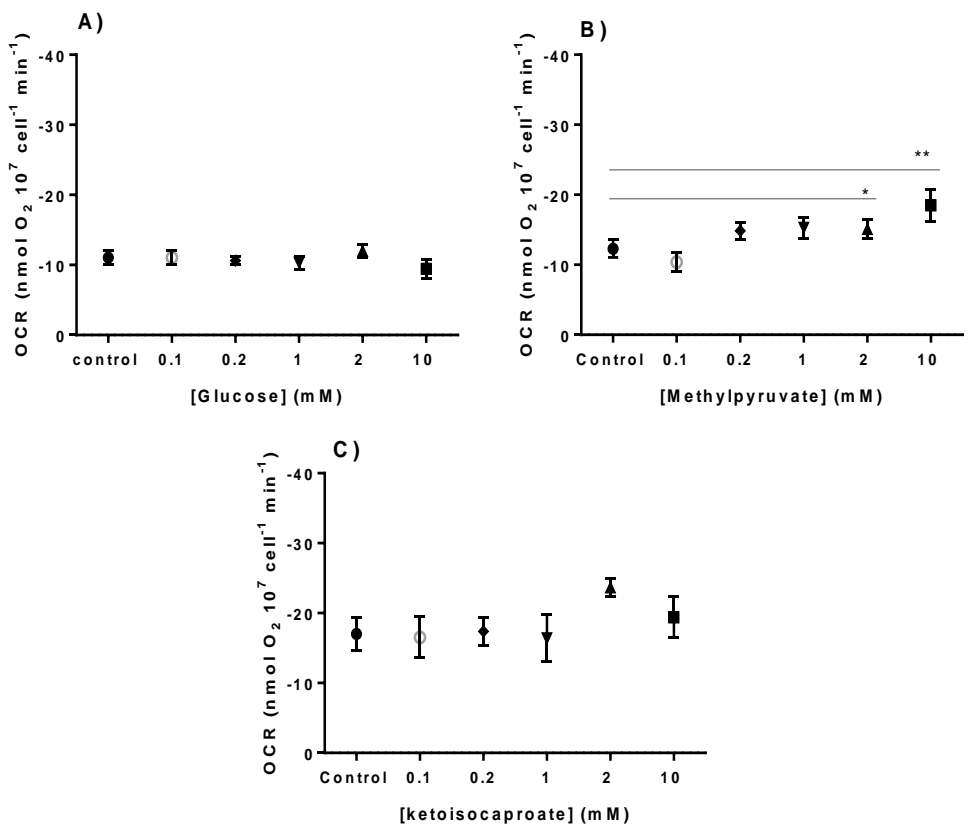

Figure 2: Relationship between glucose (A), methylpyruvate (B) and $\alpha$-ketoisocaproate (C) concentration with $\mathrm{O}_{2}$ consumption in $\mathrm{C} 6$ glioma cells. Data are mean and \pm SEM. N=6-10 experiments.

\section{Oxygen consumption rate and Lactate output}

Polarographic detection of $\mathrm{O}_{2}$ consumption and lactate output was used to measure the rate of respiration $\left(\Delta \mathrm{O}_{2}\right)$ and anaerobic glycolysis respectively. The aim of this experiment was to investigate the effect of $10 \mathrm{mM}$ glucose on the OCR and lactate production of C6 glioma cells. In the absence of exogenous metabolic substrate, suspensions of $\mathrm{C} 6$ cells consumed $\mathrm{O}_{2}\left(\Delta \mathrm{O}_{2}\right)$ at linear rate commensurate with cell density at $12 \pm 1.14$ nmoles $10^{7}$ cells $^{-1}$ $\mathrm{min}^{-1}$. Addition of $10 \mathrm{mM}$ glucose inhibited $\Delta \mathrm{O}_{2}$ by $\sim 48 \%(\mathrm{p}<0.05$, $\mathrm{t}$ test $)$ compared to the basal (Fig. 3A). However, in the absence of exogenous metabolic substrate, lactate out of $\mathrm{C} 6$ cells was linear rate commensurate with cell density at $-3 \pm 6.8$ nmoles $10^{7}$ cells $^{-1} \mathrm{~min}^{-1}$. $10 \mathrm{mM}$ glucose caused an increase in the lactate output by $\sim 122$ ( $<<0.05$, t test) compared to basal condition ( $\mathrm{p}<0.05$, t test; Fig. 3B). 
A)

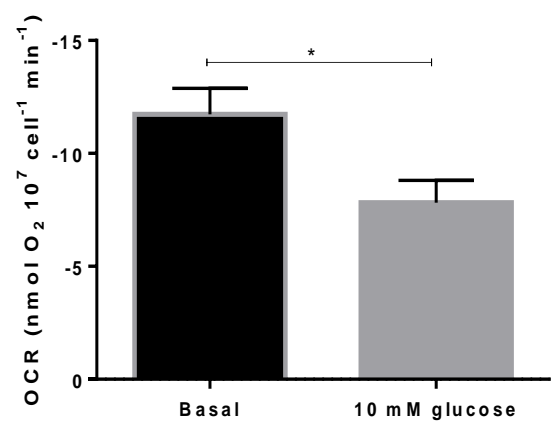

B)

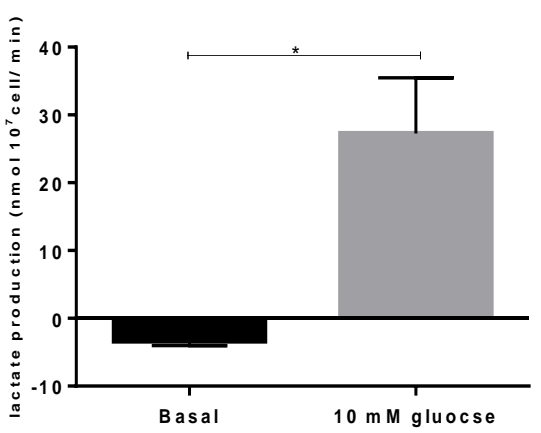

Figure 3: The effect of glucose $10 \mathrm{mM}$ on (A) Oxygen consumption rate (OCR) and (B) lactate production of C6 glioma. Data are mean \pm SEM. $N=7$ experiments.

\section{NADPH autofluoresence}

An increase in the autofluorescence signals an increase in the reduced state of the pyridine nucleotide $\mathrm{NAD}(\mathrm{P}) \mathrm{H}$. Increased activity of the tricarboxylic acid cycle may increase substrate supply and lead to an increase in NAD(P)H (Duchen et al., 1993). The aim of this experiment is to support that the lack of an OCR with glucose is indeed due to an abnormal mitochondrial oxidation. Figure 4 A shows a sample trace of the action of 10 $\mathrm{mM}$ glucose on the NAD(P)H levels of a single C6 glioma cell. Exposure of C6 glioma cells to glucose had no effect on the NAD $(\mathrm{P}) \mathrm{H}$ levels compared to the basal (Fig.4B).

A)

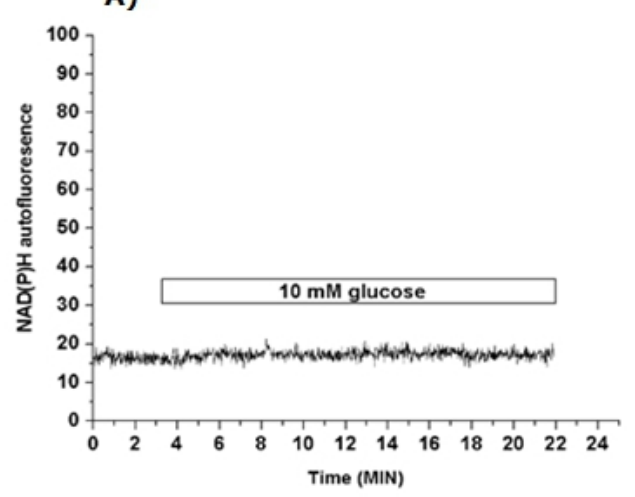

B)

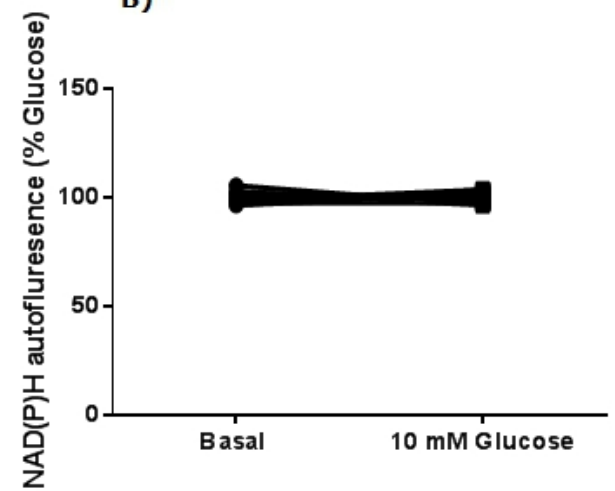

Figure 4: Effect of $10 \mathrm{mM}$ glucose on the NAD(P)H levels in the C6 glioma cells. (A) representative time course of $10 \mathrm{mM}$ glucose on the $\mathrm{NAD}(\mathrm{P}) \mathrm{H}$ levels of a single $\mathrm{C6}$ glioma cells monitored by the change in $\mathrm{NAD}(\mathrm{P}) \mathrm{H}$ fluorescence. (B) Before and after plot of NADPH fluorescence for single C6 glioma cells in response to the glucose $10 \mathrm{mM}$, the sugar had no effect on $\mathrm{NAD}(\mathrm{P}) \mathrm{H}$ levels compared to the basal. ). $\mathrm{N}=19$ cells collected from 3 experiments where the minimum number of cells is 2 in each one. 
To further explore the metabolic pathways possibly affected by fluoxetine in C6 glioma cells, other metabolic substrate that stimulates mitochondrial respiration via entry into different steps of the oxidation pathway (Duchen et al., 1993; Gao et al., 2003; Daunt et al., 2006) for glucose was used. $30 \mu \mathrm{M}$ fluoxetine had no effect in the presence $\alpha$-ketoisocaproate (Fig. 5A). However, at glucose concentration of $10 \mathrm{mM}, 30 \mu \mathrm{M}$ fluoxetine inhibited $\Delta \mathrm{O} 2$ by $\sim 21 \pm 12.36 \%$ ( $\mathrm{P}<0.05$, Dunn's multiple comparisons test) (Fig. 5B).
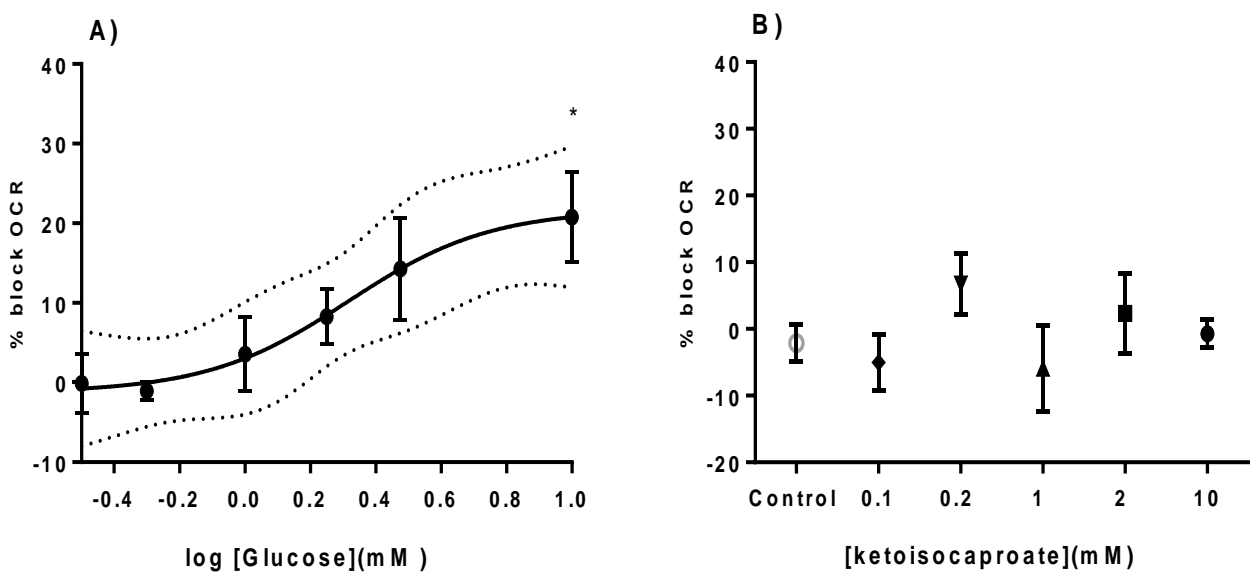

Figure 5: The percentage effect of fluoxetine in $10 \mathrm{mM}$ glucose (A) and $10 \mathrm{mM} \alpha$ ketoisocaproate (B) on the OCR in C6 glioma cells. Statistical significance is relative to the control (Cells+MTS reagent) determined via Dunnett's multiple comparisons test. Data is corrected for vehicle and background. The lines are all best fits of equation 1 to the data with $\mathrm{IC}_{50}$ given in chapter two sections 2.8 . Data are the means \pm S.E.M. $\mathrm{N}=5$ individual experiments.

I repeated the same experiment by using MTS reduction in 1.1B4. Fig. $3.8 \mathrm{~A} \& \mathrm{~B}$ shows the curve of best fit for the fluoxetine concentration-effect graph in $10 \mathrm{mM} \alpha$-ketoisocaproate and $10 \mathrm{mM}$ glucose. In $10 \mathrm{mM} \alpha$ ketoisocaproate fluoxetine failed to affect MTS reduction (Fig. 6). In $10 \mathrm{mM}$ glucose, there was a concentration-dependent decrease in MTS reduction with increasing fluoxetine concentration. The IC50 of fluoxetine inhibited MTS reduction was $4.4 \mu \mathrm{M}$ (1.70 to $0.1795 \% \mathrm{CI})$ and $\mathrm{h}$ (slope of index) of 1 ( $\mathrm{p}<$ 0.0001, Dunn's multiple comparisons test) (Fig. 6 ). These data are similar to the previous findings in MIN6 cells. This proposed that fluoxetine may inhibit metabolism at a step/s before the TCA cycle. In summary, these results explains that, a predominantly mitochondrial effect of these drugs explains these drugs target mitochondria which decrease redox status, as monitored by 
the MTS assay (Elmorsy et al., 2014), appears to be the primary cause of impairment of bioenergetics of C6 glioma cells.

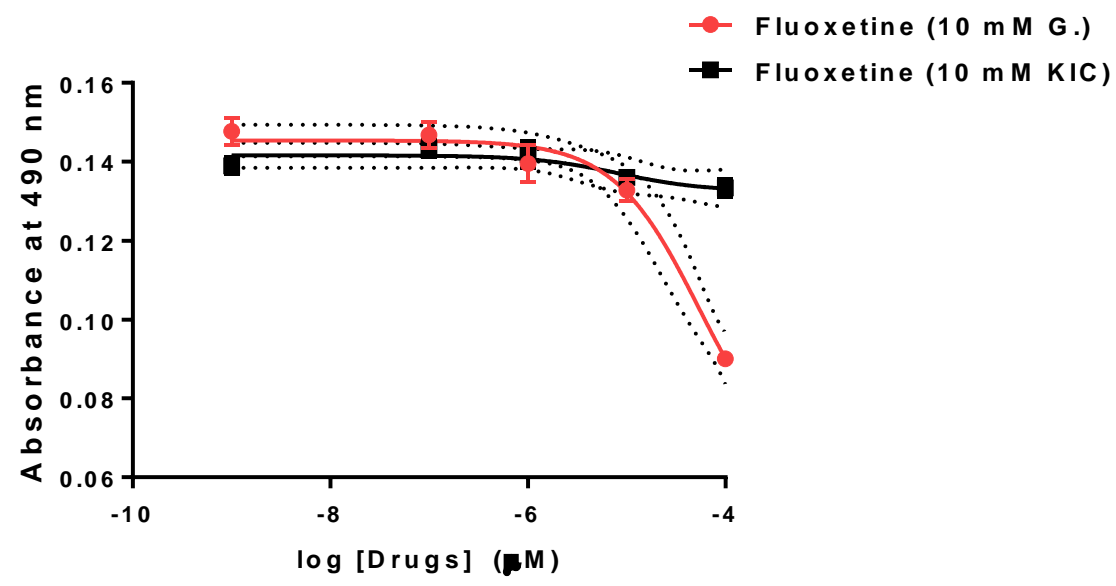

Figure 6: Concentration-effect relationships for the effect of fluoxetine in $10 \mathrm{mM}$ glucose and $10 \mathrm{mM} \alpha$-ketoisocaproate on the reduction of MTS in C6 glioma cells. Statistical significance is relative to the control (Cells+MTS reagent) determined via Dunnett's multiple comparisons test. Data is corrected for vehicle and background. The lines are all best fits of equation 1 to the data with $\mathrm{IC}_{50}$ given in chapter two sections 2.8. Data are the means \pm S.E.M. $\mathrm{N}=4$ individual experiments.

\section{Discussion}

\section{Effect of mitochondrial fuels on the MTS reduction}

Assessments of the metabolic activity of C6 glioma rat cells are very important; during the process of fuel metabolism, which are created reducing equivalents in the cytosolic and mitochondrial compartments C6 cells, which produce a measureable signal. Therefore, during static incubations of these cells with glucose may increase the signal derived via the reduction of MTS in a time and dose-dependent manner. There was a progressive increase in the MTS reduction with an increase in glucose concentration. The $\mathrm{EC}_{50}$ for glucose-stimulated MTS reduction was $1.2 \mathrm{mM}$. However, Pure mitochondrial fuels (KIC, MR or LEU) failed to affect MTS signal. These data suggest that the central importance of extra-mitochondrial, glycolytically derived reducing equivalents $\mathrm{NAD}(\mathrm{P}) \mathrm{H}$ for generation of the MTS signal (Segu et al., 1998).

\section{Metabolism}

This is the first study to investigate the catabolic metabolism on oxygen consumption rate (OCR) and lactate production of C6 glioma cells. Basal $\mathrm{O}_{2}$ consumption of $\mathrm{C} 6$ glioma cells showed a linear pattern which varied between experiments. Figure 3A showed that basal OCR at 12 nmoles $10^{7}$ cells ${ }^{-1} \mathrm{~min}^{-1}$ of C6 glioma cells. Earlier studies confirm that basal levels of 
Oxygen consumption rate were roughly $20 \mathrm{nmol} 10^{7}$ cells $^{-1} \mathrm{~min}^{-1}$ in pancreatic beta cell lines (MIN6) (Daunt et al., 2006). Difference in the basal respiration may be due to the presence of fatty acids in the cells suspensions (Lopaschuk et al., 2010) . Figure 3B showed that basal lactate production at -3 nmoles $10^{7}$ cells $^{-1} \mathrm{~min}^{-1} \mathrm{C} 6$ glioma cells. This suggests that the differences may be due to drift in the lactate electrode. No previous data had been reported for lactate output in C6 glioma cells. The 1-fold inhibition in the rate of OCR produced by $10 \mathrm{mM}$ glucose for C6 glioma cells accompanied by 6-fold stimulation in the lactate production for $\mathrm{C} 6$ glioma cells. This suggests the adding of glucose was either metabolized solely by glycolysis and apparently not by the TCA, or the cells have marginal oxidative capacity (WARBURG, 1956). This may lead to inhibit of oxidative respiration by glycolytic products Crabtree effect (Diaz-Ruiz et al., 2011).

\section{NAD(P)H levels}

The measurement of the endogenous fluorescent compound $\mathrm{NAD}(\mathrm{P}) \mathrm{H}$ serves as an indicator of glucose-induced changes of the energy metabolism (Panten et al., 1973; Duchen et al., 1993; Martens et al., 2005; Ghaly et al., 2014). As NAD(P)H autofluoresence results mainly from the mitochondria (Pralong et al., 1990; Patterson et al., 2000; Luciani et al., 2006; De Marchi et al., 2014; Ghaly et al., 2014). An increase in the fluorescence signals an increase in the reduced state of the pyridine nucleotide $\mathrm{NAD}(\mathrm{P}) \mathrm{H}$. Thus, an increased activity of the tricarboxylic acid cycle in response to increased substrate supply should lead to an increase in $\mathrm{NAD}(\mathrm{P}) \mathrm{H}$ (Duchen et al., 1993), The results denote that $10 \mathrm{mM}$ glucose did not stimulate NAD(P)H levels. This suggests that the glucose was metabolized solely by glycolysis, and not by the TCA, glucose significantly increased the lactate output with decrease of $\mathrm{NAD}(\mathrm{P}) \mathrm{H}$ levels.

\section{Fluoxetine effect the glycolytic pathway of C6 glioma cells}

In order to investigate whether the fluoxetine acts on the glycolytic pathway, my findings have reported that fluoxetine does not cause any effect on the OCR and MTS reduction whereas, it inhibited the OCR in $10 \mathrm{mM}$ glucose in C6 glioma cells. This suggests that fluoxetine may inhibit metabolism at a step/s before the TCA cycle. How does the concentration of glucose affect fluoxetine's action as shown in the Fig. 5,6. Addition of glucose may affect the $\mathrm{pH}$ of the cytosol. For example, the presence of glucose may change the cytosolic $\mathrm{pH}$ to be more acidic as a result of high rate of glycolysis in 1.1B4 cells; this in turn will attract the antidepressants such as fluoxetine which may have ionisation constants (pKa's) $>7.4$ leading to accumulate this drug in the cytosol (Lombardo et al., 2004). 


\section{Conclusion}

Our results suggest that the glycolytic pathway is the predominate path for glucose utilization in the C6 glioma cell model. Since fluoxetine was inactive in the presence of $\alpha$-ketoisocaproate our data suggest that the point of major action for these ADs in glioma cells is glycolysis.

\section{References:}

1. Abdul, M., Logothetis, C.J. and Hoosein, N.M. (1995) 'Growthinhibitory effects of serotonin uptake inhibitors on human prostate carcinoma cell lines', J Urol, 154(1), pp. 247-250.

2. Alvarez-Maubecin, V., Garcia-Hernandez, F., Williams, J.T. and Van Bockstaele, E.J. (2000) 'Functional coupling between neurons and glia', J Neurosci, 20(11), pp. 4091-4098.

3. Arimochi, H. and Morita, K. (2006) 'Characterization of cytotoxic actions of tricyclic antidepressants on human HT29 colon carcinoma cells', Eur J Pharmacol, 541(1-2), pp. 17-23.

4. Bonnet, S., Archer, S.L., Allalunis-Turner, J., Haromy, A., Beaulieu, C., Thompson, R., Lee, C.T., Lopaschuk, G.D., Puttagunta, L., Harry, G., Hashimoto, K., Porter, C.J., Andrade, M.A., Thebaud, B. and Michelakis, E.D. (2007) 'A mitochondria-K+ channel axis is suppressed in cancer and its normalization promotes apoptosis and inhibits cancer growth', Cancer Cell, 11(1), pp. 37-51.

5. Brandes, L.J., Arron, R.J., Bogdanovic, R.P., Tong, J., Zaborniak, C.L., Hogg, G.R., Warrington, R.C., Fang, W. and LaBella, F.S. (1992) 'Stimulation of malignant growth in rodents by antidepressant drugs at clinically relevant doses', Cancer Res, 52(13), pp. 3796-3800.

6. Brown, A.M., Baltan Tekkök, S. and Ransom, B.R. (2004) 'Energy transfer from astrocytes to axons: the role of CNS glycogen', Neurochem Int, 45(4), pp. 529-536.

7. Brown, A.M., Evans, R.D., Black, J. and Ransom, B.R. (2012) 'Schwann cell glycogen selectively supports myelinated axon function', Ann Neurol, 72(3), pp. 406-418.

8. Brown, L.C., Majumdar, S.R. and Johnson, J.A. (2008) 'Type of antidepressant therapy and risk of type 2 diabetes in people with depression', Diabetes Res Clin Pract, 79(1), pp. 61-67.

9. Cairns, R.A., Harris, I.S. and Mak, T.W. (2011) 'Regulation of cancer cell metabolism', Nat Rev Cancer, 11(2), pp. 85-95.

10. Cory, A.H., Owen, T.C., Barltrop, J.A. and Cory, J.G. (1991) 'Use of an aqueous soluble tetrazolium/formazan assay for cell growth assays in culture', Cancer Commun, 3(7), pp. 207-212.

11. Daley, E., Wilkie, D., Loesch, A., Hargreaves, I.P., Kendall, D.A., Pilkington, G.J. and Bates, T.E. (2005) 'Chlorimipramine: a novel 
anticancer agent with a mitochondrial target', Biochem Biophys Res Commun, 328(2), pp. 623-632.

12. Daunt, M., Dale, O. and Smith, P.A. (2006) 'Somatostatin inhibits oxidative respiration in pancreatic beta-cells', Endocrinology, 147(3), pp. 1527-1535.

13. Derijks, H.J., Meyboom, R.H., Heerdink, E.R., De Koning, F.H., Janknegt, R., Lindquist, M. and Egberts, A.C. (2008) 'The association between antidepressant use and disturbances in glucose homeostasis: evidence from spontaneous reports', Eur J Clin Pharmacol, 64(5), pp. 531-538.

14. Diaz-Ruiz, R., Rigoulet, M. and Devin, A. (2011) 'The Warburg and Crabtree effects: On the origin of cancer cell energy metabolism and of yeast glucose repression', Biochim Biophys Acta, 1807(6), pp. 568576.

15. Dienel, G.A. and Cruz, N.F. (2006) 'Astrocyte activation in working brain: energy supplied by minor substrates', Neurochem Int, 48(6-7), pp. 586-595.

16. Dringen, R., Gebhardt, R. and Hamprecht, B. (1993) 'Glycogen in astrocytes: possible function as lactate supply for neighboring cells', Brain Res, 623(2), pp. 208-214.

17. Duchen, M.R., Smith, P.A. and Ashcroft, F.M. (1993) 'Substratedependent changes in mitochondrial function, intracellular free calcium concentration and membrane channels in pancreatic betacells', Biochem J, 294 ( Pt 1), pp. 35-42.

18. Elmorsy, E., Elzalabany, L.M., Elsheikha, H.M. and Smith, P.A. (2014) 'Adverse effects of antipsychotics on micro-vascular endothelial cells of the human blood-brain barrier', Brain Res, 1583, pp. 255-268.

19. Gao, Z., Young, R.A., Li, G., Najafi, H., Buettger, C., Sukumvanich, S.S., Wong, R.K., Wolf, B.A. and Matschinsky, F.M. (2003) 'Distinguishing features of leucine and alpha-ketoisocaproate sensing in pancreatic beta-cells', Endocrinology, 144(5), pp. 1949-1957.

20. Gee, J.R. and Keller, J.N. (2005) 'Astrocytes: regulation of brain homeostasis via apolipoprotein E', Int J Biochem Cell Biol, 37(6), pp. 1145-1150.

21. Ghosh, A., Cheung, Y.Y., Mansfield, B.C. and Chou, J.Y. (2005) 'Brain contains a functional glucose-6-phosphatase complex capable of endogenous glucose production', J Biol Chem, 280(12), pp. 1111411119.

22. Hamprecht, B., Verleysdonk, S. and Wiesinger, H. (2005) Neuroglia, New York, oxford University Press. 
23. Hu, W., Onuma, T., Birukawa, N., Abe, M., Ito, E., Chen, Z. and Urano, A. (2008) 'Change of morphology and cytoskeletal protein gene expression during dibutyryl cAMP-induced differentiation in C6 glioma cells', Cell Mol Neurobiol, 28(4), pp. 519-528.

24. Janjic, D. and Wollheim, C.B. (1992) 'Islet cell metabolism is reflected by the MTT (tetrazolium) colorimetric assay', Diabetologia, 35(5), pp. 482-485.

25. Jijakli, H., Nadi, A.B., Cook, L., Best, L., Sener, A. and Malaisse, W.J. (1996) 'Insulinotropic action of methyl pyruvate: enzymatic and metabolic aspects', Arch Biochem Biophys, 335(2), pp. 245-257.

26. Kiss, J.P. (2008) 'Theory of active antidepressants: a nonsynaptic approach to the treatment of depression', Neurochem Int, 52(1-2), pp. 34-39.

27. Kreutzberg, G.W. (1996) 'Microglia: a sensor for pathological events in the CNS', Trends Neurosci, 19(8), pp. 312-318.

28. Kubera, M., Grygier, B., Arteta, B., Urbańska, K., Basta-Kaim, A., Budziszewska, B., Leśkiewicz, M., Kołaczkowska, E., Maes, M., Szczepanik, M., Majewska, M. and Lasoń, W. (2009) 'Age-dependent stimulatory effect of desipramine and fluoxetine pretreatment on metastasis formation by B16F10 melanoma in male C57BL/6 mice', Pharmacol Rep, 61(6), pp. 1113-1126.

29. Levkovitz, Y., Gil-Ad, I., Zeldich, E., Dayag, M. and Weizman, A. (2005) 'Differential induction of apoptosis by antidepressants in glioma and neuroblastoma cell lines: evidence for p-c-Jun, cytochrome c, and caspase-3 involvement', J Mol Neurosci, 27(1), pp. 29-42.

30. Lopaschuk, G.D., Ussher, J.R., Folmes, C.D., Jaswal, J.S. and Stanley, W.C. (2010) 'Myocardial fatty acid metabolism in health and disease', Physiol Rev, 90(1), pp. 207-258.

31. Luciani, D.S., Misler, S. and Polonsky, K.S. (2006) 'Ca2+ controls slow NAD $(\mathrm{P}) \mathrm{H}$ oscillations in glucose-stimulated mouse pancreatic islets', J Physiol, 572(Pt 2), pp. 379-392.

32. Lustman, P.J., Griffith, L.S., Gavard, J.A. and Clouse, R.E. (1992) 'Depression in adults with diabetes', Diabetes Care, 15(11), pp. 16311639.

33. Madhok, B.M., Yeluri, S., Perry, S.L., Hughes, T.A. and Jayne, D.G. (2010) 'Dichloroacetate induces apoptosis and cell-cycle arrest in colorectal cancer cells', Br J Cancer, 102(12), pp. 1746-1752.

34. Magistretti, P.J. (2008a) Fundemental Neuroscience, San Diego.

35. Magistretti, P.J. (2008b) Fundemental Neuroscience $3^{\text {rd }}$, San Diego, Squire,L.R. Berg, D. Bloom,F.E. du

Lac,S. Ghosh,A. Spitzer, N.C.eds 
36. Mercier, G., Lennon, A.M., Renouf, B., Dessouroux, A., Ramaugé, M., Courtin, F. and Pierre, M. (2004) 'MAP kinase activation by fluoxetine and its relation to gene expression in cultured rat astrocytes', J Mol Neurosci, 24(2), pp. 207-216.

37. Michelakis, E.D., Webster, L. and Mackey, J.R. (2008) 'Dichloroacetate (DCA) as a potential metabolic-targeting therapy for cancer', Br J Cancer, 99(7), pp. 989-994.

38. Neves, A., Costalat, R. and Pellerin, L. (2012) 'Determinants of brain cell metabolic phenotypes and energy substrate utilization unraveled with a modeling approach', PLoS Comput Biol, 8(9), p. e1002686.

39. Occhipinti, R., Puchowicz, M.A., LaManna, J.C., Somersalo, E. and Calvetti, D. (2007) 'Statistical analysis of metabolic pathways of brain metabolism at steady state', Ann Biomed Eng, 35(6), pp. 886-902.

40. Patterson, G.H., Knobel, S.M., Arkhammar, P., Thastrup, O. and Piston, D.W. (2000) 'Separation of the glucose-stimulated cytoplasmic and mitochondrial NAD $(\mathrm{P}) \mathrm{H}$ responses in pancreatic islet beta cells', Proc Natl Acad Sci U S A, 97(10), pp. 5203-5207.

41. Pierre, K. and Pellerin, L. (2005) 'Monocarboxylate transporters in the central nervous system: distribution, regulation and function', $J$ Neurochem, 94(1), pp. 1-14.

42. Pralong, W.F., Bartley, C. and Wollheim, C.B. (1990) 'Single islet beta-cell stimulation by nutrients: relationship between pyridine nucleotides, cytosolic Ca2+ and secretion', EMBO J, 9(1), pp. 53-60.

43. Rinholm, J.E., Hamilton, N.B., Kessaris, N., Richardson, W.D., Bergersen, L.H. and Attwell, D. (2011) 'Regulation of oligodendrocyte development and myelination by glucose and lactate', J Neurosci, 31(2), pp. 538-548.

44. Russo-Neustadt, A.A., Alejandre, H., Garcia, C., Ivy, A.S. and Chen, M.J. (2004) 'Hippocampal brain-derived neurotrophic factor expression following treatment with reboxetine, citalopram, and physical exercise', Neuropsychopharmacology, 29(12), pp. 21892199.

45. Segu, V.B., Li, G. and Metz, S.A. (1998) 'Use of a soluble tetrazolium compound to assay metabolic activation of intact beta cells', Metabolism, 47(7), pp. 824-830.

46. Spanová, A., Kovárů, H., Lisá, V., Lukásová, E. and Rittich, B. (1997) 'Estimation of apoptosis in C6 glioma cells treated with antidepressants', Physiol Res, 46(2), pp. 161-164.

47. Srebro, Z. and Dziobek, K. (2001) 'Neuroprotection: the role of neuroglia', Folia Med Cracov, 42(3), pp. 113-121.

48. Stockwin, L.H., Yu, S.X., Borgel, S., Hancock, C., Wolfe, T.L., Phillips, L.R., Hollingshead, M.G. and Newton, D.L. (2010) 'Sodium 
dichloroacetate selectively targets cells with defects in the mitochondrial ETC', Int J Cancer, 127(11), pp. 2510-2519.

49. Tardy, M., Le Prince, G., Fages, C., Rolland, B., Nunez, J. and Belin, M.F. (1991) 'Neuron-glia interaction. Effect of serotonin and DBcAMP on the expression of GFAP and its encoding message', Ann NY Acad Sci, 633, pp. 630-632.

50. Vilchez, D., Ros, S., Cifuentes, D., Pujadas, L., Vallès, J., GarcíaFojeda, B., Criado-García, O., Fernández-Sánchez, E., MedrañoFernández, I., Domínguez, J., García-Rocha, M., Soriano, E., Rodríguez de Córdoba, S. and Guinovart, J.J. (2007) 'Mechanism suppressing glycogen synthesis in neurons and its demise in progressive myoclonus epilepsy', Nat Neurosci, 10(11), pp. 14071413.

51. WARBURG, O. (1956) 'On the origin of cancer cells', Science, 123(3191), pp. 309-314. 